\title{
AN OVERVIEW OF RESEARCH ON MARKETING ETHICS EDUCATION
}

\section{PREGLED ISTRAŽIVANJA 0 OBRAZOVANJU U PODRUČJU MARKETINŠKE ETIKE}

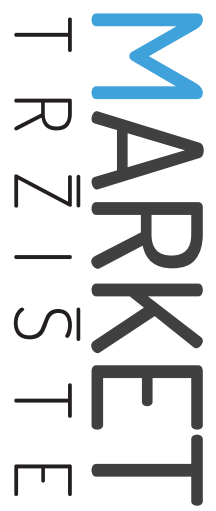

Market-Trziste

Vol. 28, No. 2, 2016, pp. 131-142

UDK 658.8:174:37

Review

\author{
Daniela Hrehováa, Pavel Žiaran ${ }^{\text {b }}$ \\ a) Technical University in Kosice, Vysokoškolská 4, 04200 Košice, SLOVAK REPUBLIC, daniela.hrehova@tuke.sk \\ b) Mendel University in Brno, Faculty of Business and Economics, Zemědělská 1, 61300 Brno, CZECH REPUBLIC, pziaran@gmail.com
}

\begin{abstract}
Purpose - Last two decades have seen a marked increase in the interest given to the field of business ethics, particularly, marketing ethics. Marketing ethics provides an innumerable amount of materials and topics for open discussion, as well as for application in practice. Our intention is to open up a space within which to promote timely debate on contemporary marketing education.
\end{abstract}

Design/Methodology/Approach - Monitoring of academic journals in the area of marketing ethics tuition accessible in electronic databases (EBSCO, ProQuest, Web of Science, Google Scholar) by means of the Centre for scientific-technical information SR portal.

The work is based on the analysis of thematic categories, and the number of publications and citations. Results are presented in a comprehensive and illustrative manner.

Findings and implications - Discussions about marketing ethics and ethical issues are useful. Students need preparation, mentoring and counselling while solving ethical problems, which occur during marketing ethics tuition in the academic field, but also in practice. Academic and scientific sources in the area of marketing ethics education are an excellent "instruction".

Limitations - The limitation of this research can be seen in the fact that we focused especially on the marketing aspect of the ethics education. In further research, other fields of interest should be addressed, for example management or practices in commerce, etc.

\section{Sažetak}

Svrha - Posljednja dva desetljeća povećan je interes za područje poslovne etike, posebice marketinške. Marketinška etika nudi bezbroj materijala i tema za otvorenu raspravu kao i za primjenu u praksi. Namjeravamo otvoriti prostor unutar kojega će se promicati pravovremena rasprava o suvremenom marketinškom obrazovanju.

Metodološki pristup - Praćeni su znanstveni časopisi iz područja marketinške etike dostupni u elektroničkim bazama podataka (EBSCO, ProQuest, Web of Science, Google Scholar) korištenjem portala Centre for scientific-technical information. Rad se temelji na analizi tematskih kategorija, broju publikacija i citata. Rezultati su prikazani na sveobuhvatan i slikovit način.

Rezultati i implikacije - Rasprave o marketinškoj etici i etičkim pitanjima korisne su. Studenti trebaju pripremu, mentorstvo i savjetovanje pri rješavanju etičkih problema do kojih dolazi za vrijeme obrazovanja iz marketinške etike $u$ akademskom okružju, ali i u praksi. Akademski i znanstveni izvori u području obrazovanja iz marketinške etike izvrsne su "upute".

Ograničenja - Odnosi se na činjenicu da je istraživanje usredotočeno na marketinški aspekt u obrazovanju o etici. $U$ daljnjim istraživanjima trebalo bi obuhvatiti druga područja od interesa kao, na primjer, menadžment ili prakse u prodaji itd. 
Originality - The aim of the article is to map current trends in research in the field of marketing ethics education, as presented in scientific journals.

Keywords - ethics, marketing, education
Doprinos - Cilj je članka mapirati aktualne trendove istraživanja u području obrazovanja iz marketinške etike kao što je to predstavljeno u znanstvenim časopisima.

Ključne riječi - etika, marketing, obrazovanje 


\section{INTRODUCTION}

Business ethics and culture are establishing a new focus on morality in thinking nowadays. Education in business ethics helps morality to penetrate into the economic and trade relations, and it impacts the efficiency of the business environment. Business ethics has a deeper meaning than a mere application of laws and regulations. It represents a set of rules and principles that provide guidelines for appropriate behavior and action in specific business situations (Lewis, 1985). Business ethics was shaped as an independent scientific and pedagogic field with its own research applied in different fields of business, such as accounting, financial management, human resources, sales, logistic, marketing and marketing communication, etc.

Marketing ethics may be defined as a subset of business ethics, since ethics in business is a part of wider and complex studies of ethics (Martin, 1985). Marketing ethics is affected by changes in the marketing environment, legislation, regulation, or actual conduct of the company (customers, suppliers, etc.). Marketing ethics refers to the application of ethical principles in the creation and implementation of the marketing strategy and individual elements of the marketing mix. For example, elimination of misleading advertising, pricing, selling dangerous products without notice to the customer, or use of illegal distribution channels (Kotler \& Armstrong, 2004). Considering that marketing ethics is an interdisciplinary area, including a wide spectrum from marketing, management, finance, and accountancy to philosophy, politics, and law, it requires general knowledge of both students and academicians. Marketing ethics provides an innumerable amount of materials and topics for open discussion, as well as for application in practice. The main goal of our research is to monitor and measure ethical values and attitudes. The results of our analysis should show a relevant level of ethics and serve for future preparation of study materials. The analysed study field will create a platform to be implemented in courses for teaching marketing ethics. The importance of marketing ethics in business resonates in the need to introduce marketing ethics education at universities. This naturally brings a wide range of methodological issues, such as the most suitable bibliographical resources, teaching methodology and pedagogic infrastructure, having in mind the objective to transform inner values and attitudes of students, and to promote their implementation in the business practice.

\section{MARKETING ETHICS IN EDUCATION}

The issue of marketing ethics is becoming the object of attention of both researchers and the business community. Empirical and theoretical studies paint the picture of the functioning of marketing ethics. This picture is than transformed into study materials for high schools, universities and practitioners. The materials are often illustrated by the life experiences of the people who have lived through interesting, ethically sensitive situations. Several studies provide definitions of marketing ethics (Kotler \& Armstrong, 2010; Murphy \& Laczniak, 2006; Baker \& Saren, 2010; Brenkert, 2008; Schminke, 2001; Andersen, 2001), on the basis of which we can provide a general definition of marketing ethics as a multidimensional scientific discipline (theoretical and applied), which examines compliance with the general principles of ethics in various marketing activities. It represents a set of general principles of morality that every employee or business has to observe and respect in trade relations, advertising, pricing, customer service, and product development, as well as general ethical standards.

Marketing ethics can be understood as an application of moral standards to companies, in their marketing decisions and market behaviour. Adherence to ethical principles in marketing creates competitive advantage for the company, in turn helping to fulfill the objectives set by the organization. Marketing ethics can be 
seen as a systematic thinking on the moral implications of decisions (Butorácová, 2009). New types of marketing campaigns and strategies are based on so-called "black hat" activities that are not banned. New media and a faster lifestyle brought to marketing unethical trends. Traditional ways are considered too loserly and ineffective, because of the absence of marketing ethics education.

Research in the education of marketing ethics is not a consistent research stream. Rather, it represents a dispersed set of ad hoc efforts, often based on different intellectual foundations and behavioral paradigms. One of the major research question concerns the effects of ethical education as addressed by the following authors. Harris (2008) in his study points out that training in marketing ethics is in the center of attention of the majority of business schools and economics faculties. Relatively recent ethical scandals, such as that of Enron and Arthur Andersen or WorldCom, have led to the debate on a compulsory education of ethics (McAlister, Ferrell \& Ferrell, 2010), as well as to the debate on to what depth and width should ethics be taught. Gaski (1999) affirms that the education of marketing ethics should follow the standards applicable in practice. Hunt and Laverie (2004) are of the opinion that the training in ethics can change and improve the awareness of ethical issues and ethical thinking. However, according to Barnett, Dascher and Nicholson (2004), most educational programs are insufficient. Spain, Engle and Thompson (2005) indicate that the lack of knowledge of marketing ethics can have a major impact on the career development of future graduates. Therefore, ethical education has been included among the priorities at many business schools (Buff \& Yonkers, 2004). Several authors propose a wide range of concepts and approaches for teaching business ethics in marketing (Anderson, 1997; Baxter \& Rarick, 1997; Cragg, 1997; Raisner, 1997; Wolfe \& Fritzsche, 1998).

Porter and McKibbin (1988), based on the extensive survey among students, academics and employers, found that economic faculties and business schools focus too much on hard skills and knowledge, and not sufficiently on the behavioral aspects and soft skills. Universities play an important role in shaping ethical attitudes that the new generation will apply in the marketing practice. The approach of teachers in respect of ethics has a significant impact on students as future practitioners (Shannon \& Berl, 1997). Spain and others (2005) state the need for more illustrative teaching to understand the content of marketing ethics and its subsequent use in practice. Chonko (2004) suggests the use of a combination of case studies, lectures, discussions, and tasks for students. Furthermore, Wolfe and Fritzsche (1998) propose the use of games and ethical dilemmas in business in teaching ethics.

Another question has been raised on the structure of teaching, namely, should ethics be taught as an integral part of different subjects or should it be taught as a specialized module? Haas (2005) concludes, based on a research study conducted among students, that the preferred option is that in which ethics is distributed among various subjects. Marketing ethics should be included in several subjects, such as introduction to marketing, marketing management, strategic marketing, marketing research, digital/new marketing media, marketing of services and brand marketing. According to Bauman (1995), the implementation of ethical modules has a considerable impact on the development of the moral "self" of a student. Harris (2008) claims that a teacher has an opportunity to do more than just providing technical skills for the marketing decision-making. Ethical education should help to build the responsibility for the conduct in business and the ability to discern right from wrong, ethical from unethical (Ruiz, 2004). Some academicians perceive marketing as a more economical and empirical discipline (Brennan, Nick \& Higgins, 2010). Tadajewski (2008) comments that academics in marketing more than in other disciplines have the tendency to succumb regularly to forgetfulness as regards ethical principles. Chonko (2004) 

teaching methods, including case studies, lectures, assignments, and discussions.

\section{LITERATURE SOURCES IN MARKETING ETHICS}

The aim of the review is to structure the academic resources in the field of marketing ethics education. The methodology is based on the article authored by Schlegelmilch and Obersedeer (2010), titled "Half a Century of Marketing Ethics: Shifting Perspectives and Emerging Trends". An earlier research study on a similar topic was published by Loe and Ferell (2001). In the first step of this research, we summarized the most important academic resources in business ethics based on the previous studies. In the next step, we provide an analysis of academic resources in the field of business ethics education in general. We believe that the areas such as ethics in accounting or management offer a number of important ideas that can be implemented in the field of marketing ethics.

\subsection{Methodology of the monitoring of educational resources in the area of "ethics - marketing - teaching"}

Objective of research: monitoring of scientific journals in the field of Ethics - Marketing - Education.

Time range: according to the availability of databases.

Databases used: access through the Centre of Scientific and Technical Information portal (Slovakia), a bibliographic database with access to full-text documents, namely: Business Source Premier (EBSCO part of the offer), ERIC (the Jour-

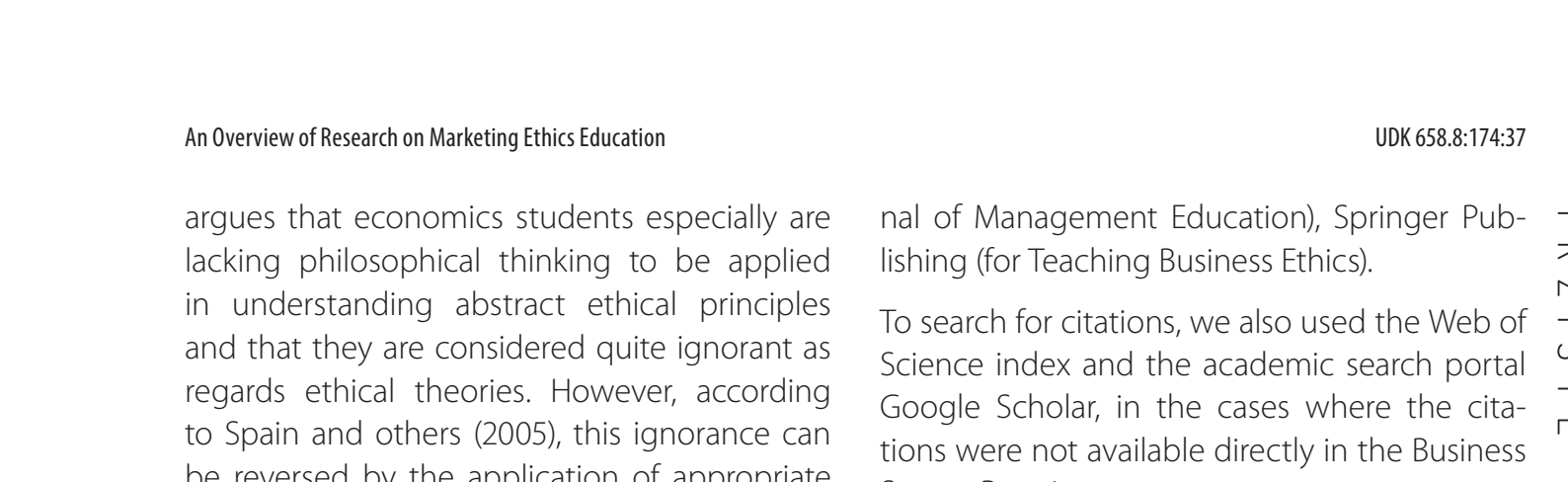

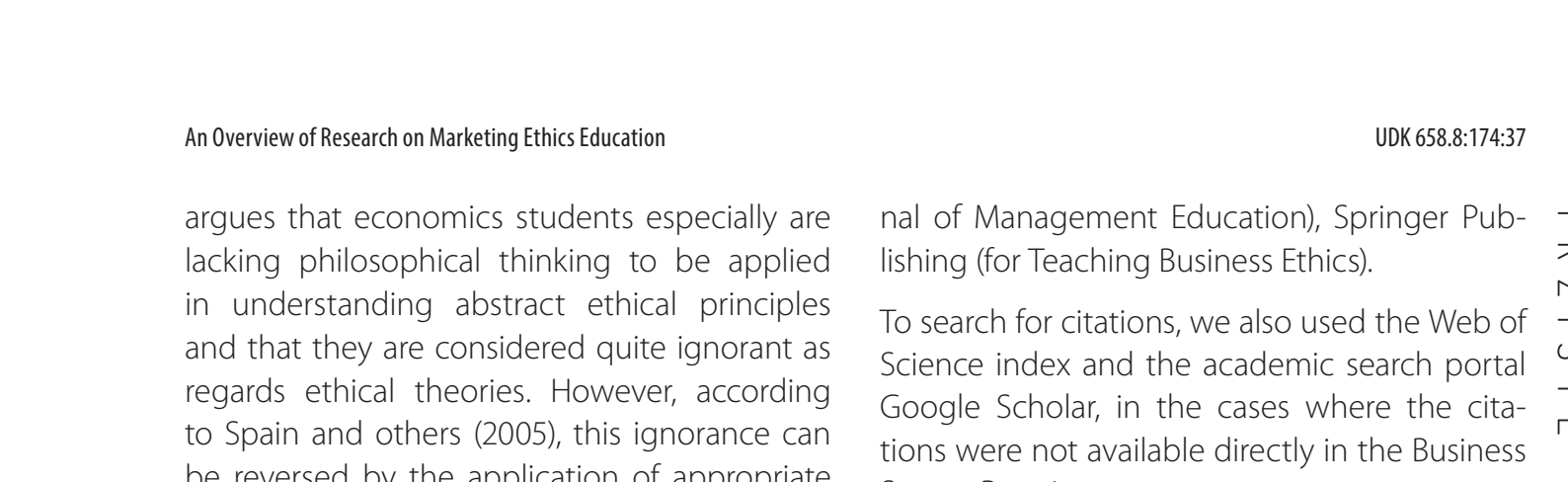

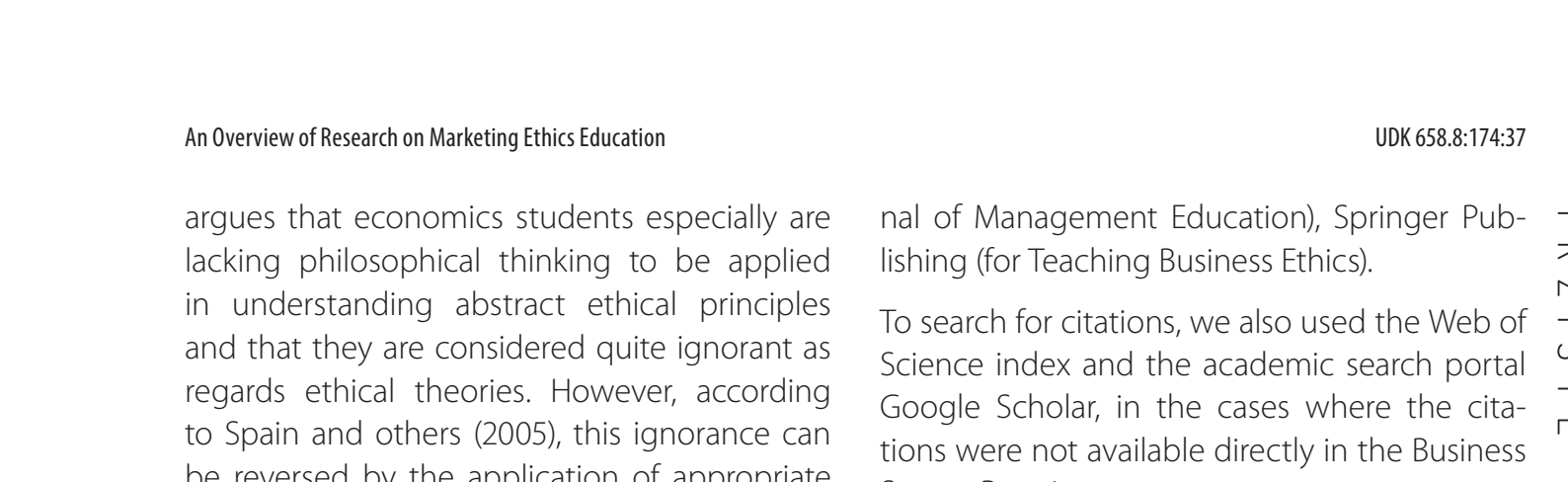

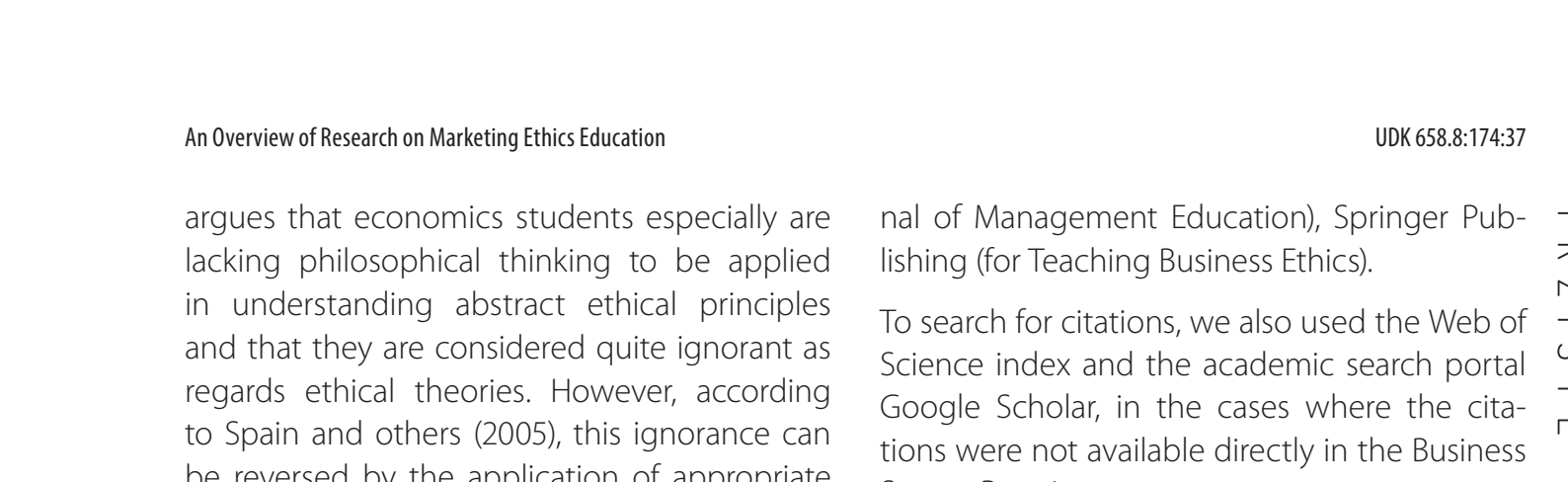

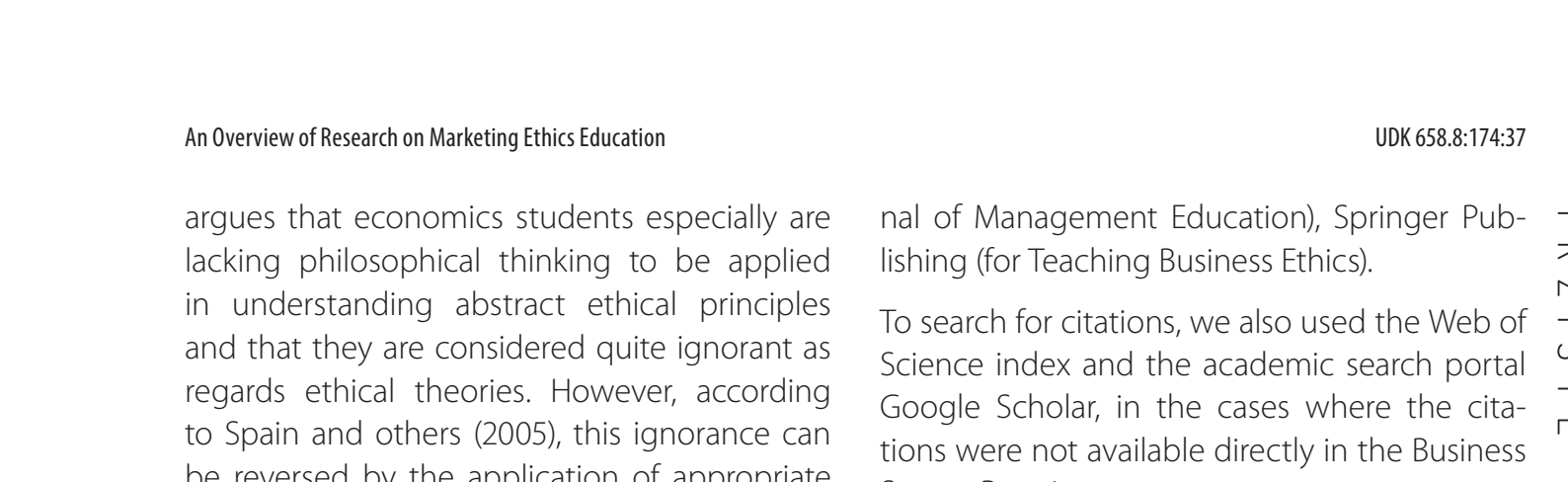

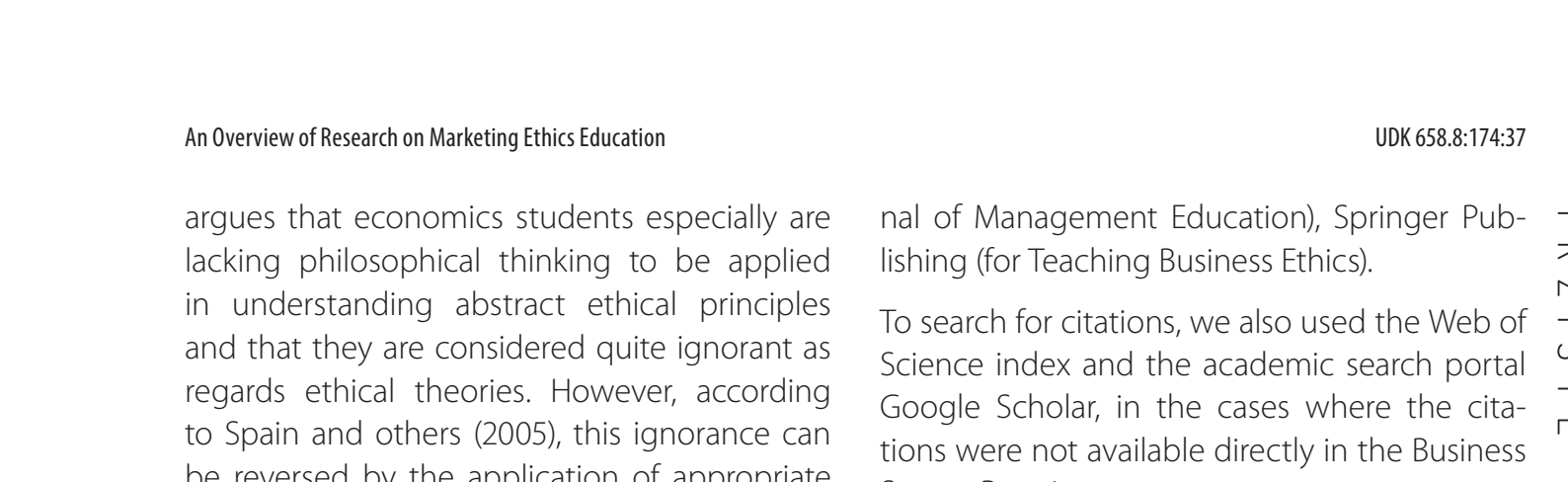

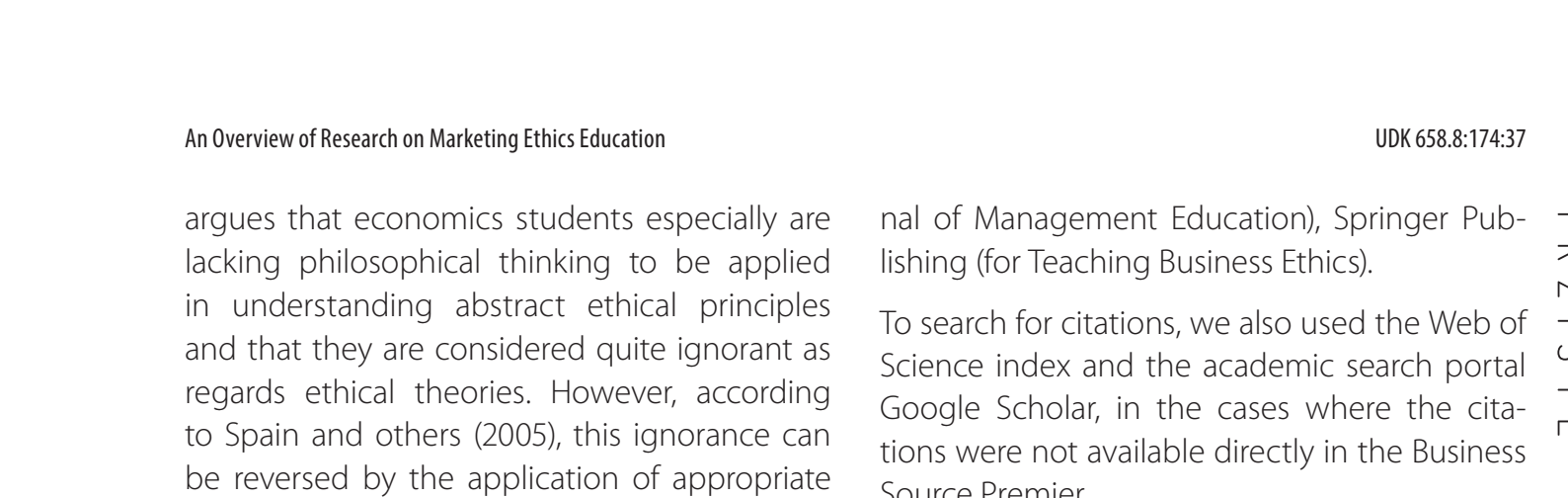
Source Premier.

\section{Search settings:}

Source - Journal Title - in determining the number of magazines for the whole area, for example marketing, or in combination with NOT operator for journals that have already been used in other sections.

Keywords (Subject Terms) - in journals, that do not deal primarily with ethics, for example journals specialized in marketing, the key words were: "ethics", "ethical", "education"; the key word "marketing" in journals that do not deal primarily with marketing; we also monitored some journals in the field of accounting, management, and communication, on the condition that these deal intensively with ethics.

Procedure: (1) We focused our attention on the content of monitored scientific and scholarly publications, which are of double character. (2) We paid attention to positive and negative attitudes towards marketing ethics education from the point of view of significant academicians and experts. (3) We summarised the most important literary sources in the marketing ethics area: (a) we investigated scientific sources in the area of entrepreneurial ethics tuition in general, as well as the position represented by the area of marketing ethics; (b) we analysed its content and its structure in academic journals in the specific area of marketing ethics tuition. The methodological and ideological basis for our survey was the publication "Half a Century of Marketing Ethics: Shifting Perspectives and Emerging Trends" by the authors Schlegelmilch and Obersedeer. It was our goal to find an optimal result, i.e. the articles dealing with the area of marketing ethics tuition, so we tested various combinations of logical information retrieval items for each journal individually and databas-

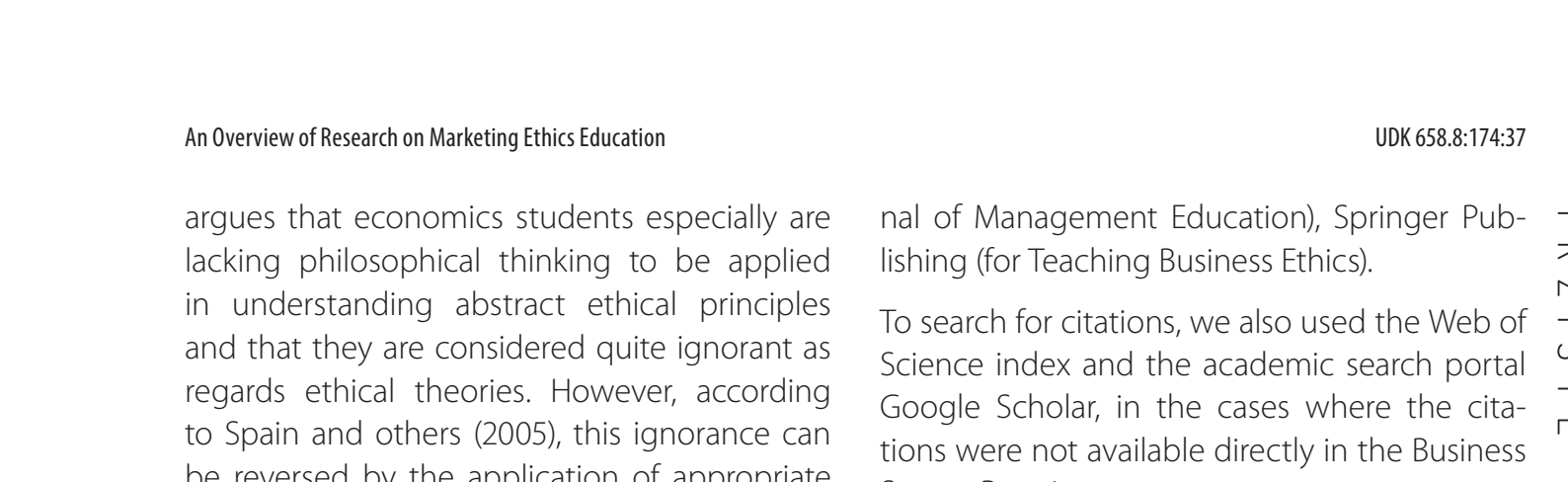

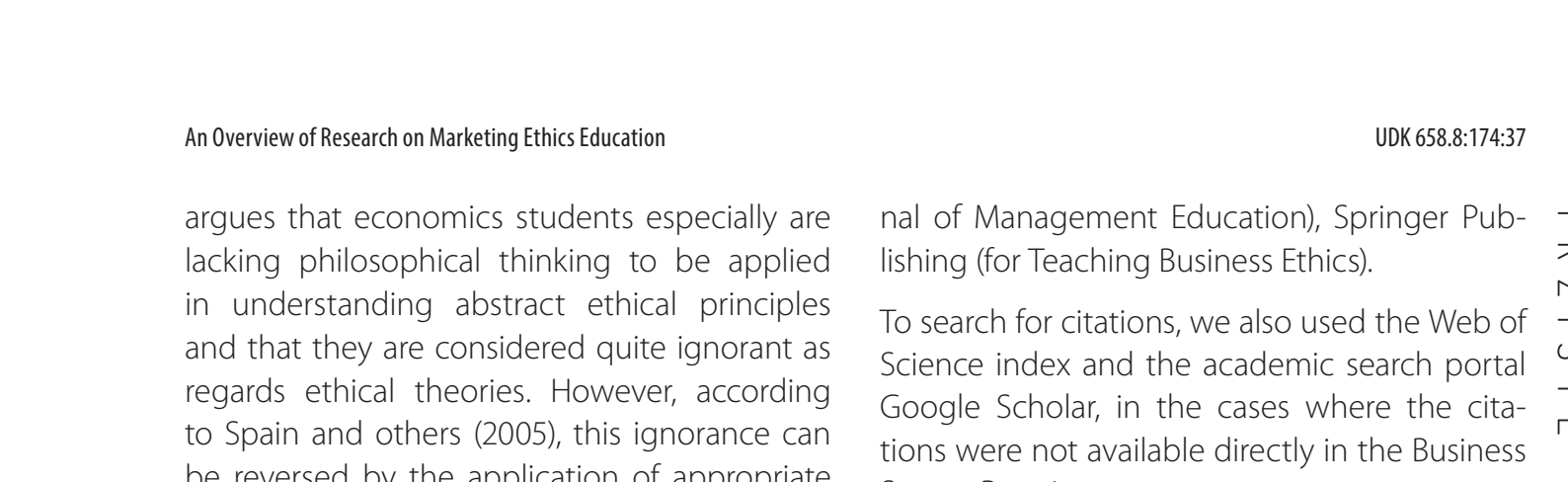

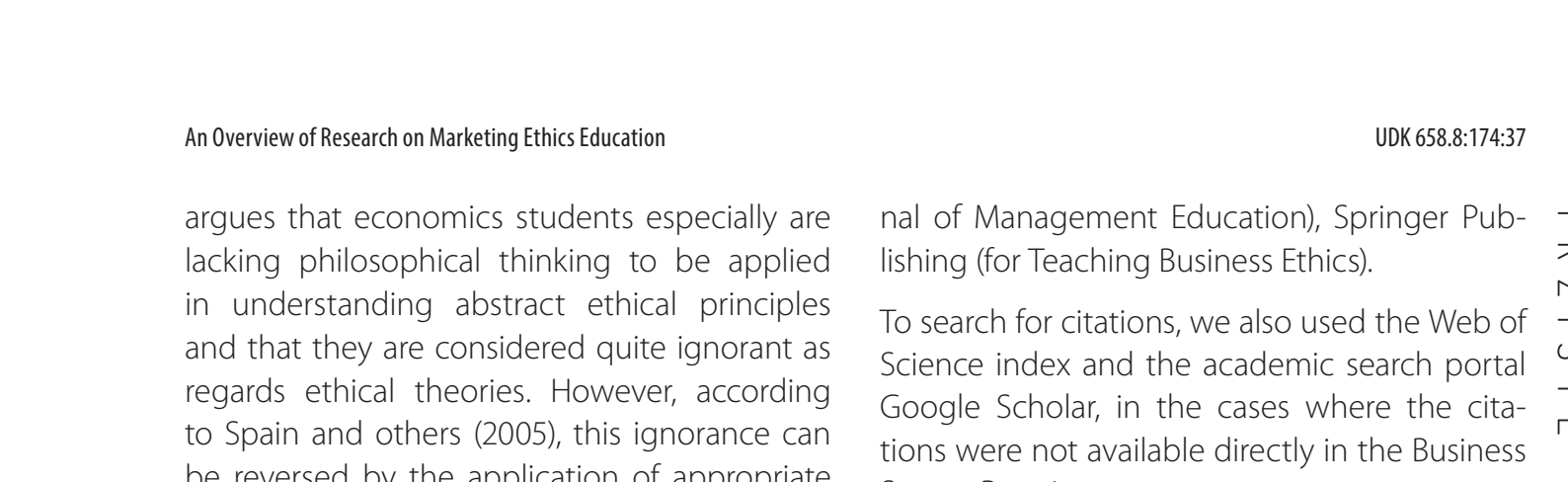

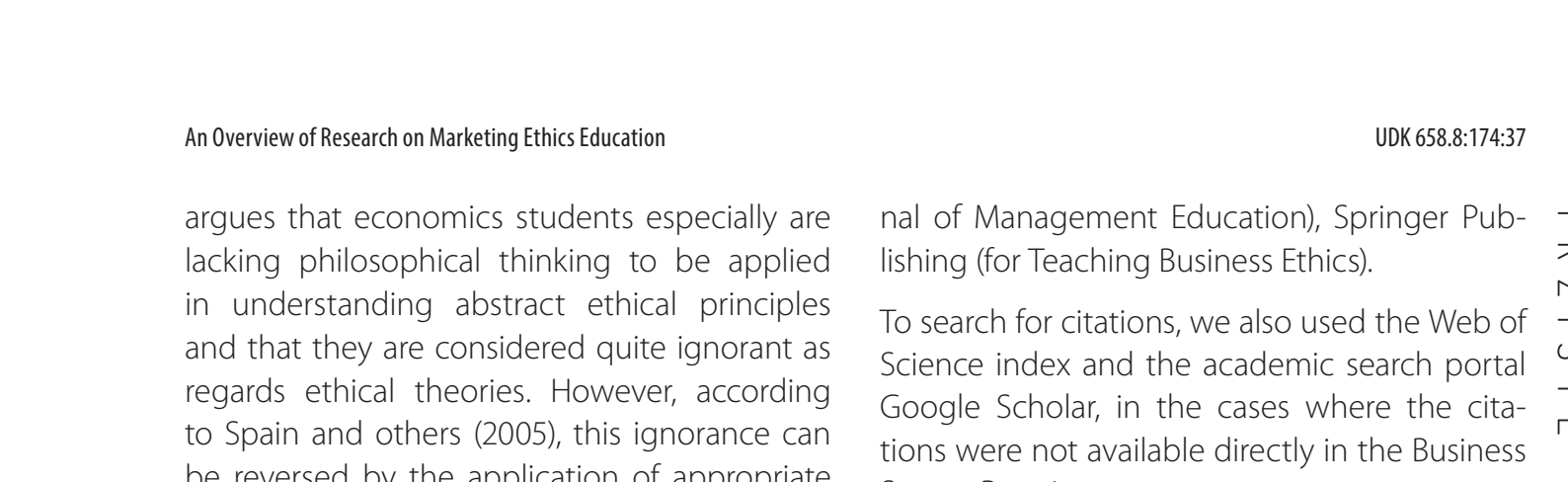

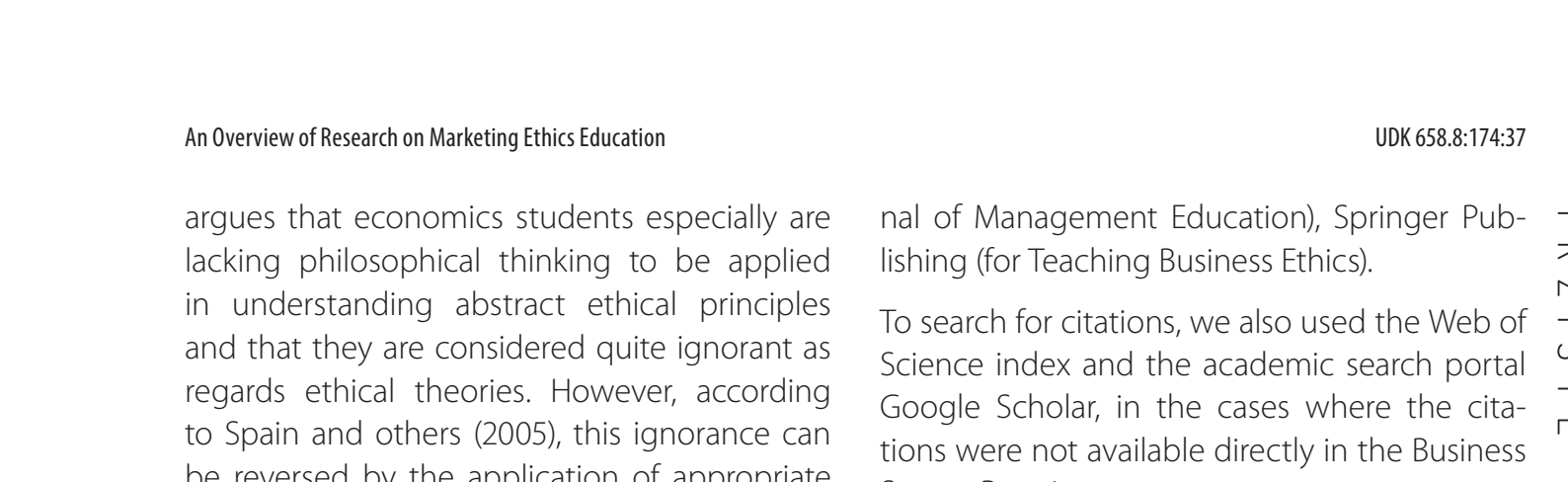

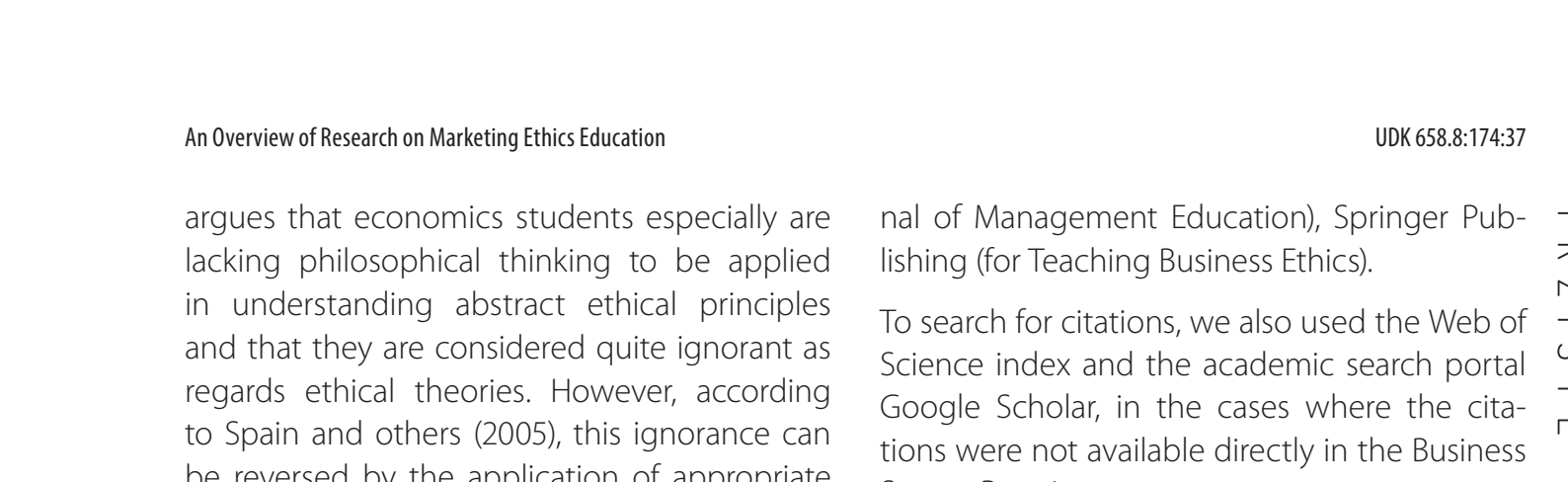

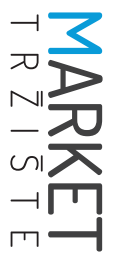

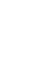


es EBSCO, ProQuest, Web of Science, Google Scholar, ABI/Inform, Business Source Premier. From the journal review, we suggested six categories: measurement of ethical values and attitudes; particular pedagogical methods; proposal and structure of course in ethics; measurement of education efficiency, ethics integration on the Faculty level; ethical codices and norms, (1) in order to be highly consistent and relevant for categorization of the journals, and (2) to enable the monitoring of academic knowledge and research trends in this area in a clear and comprehensible manner. We have elaborated in the survey our own "local" impact factor for the specific area of marketing ethics education and tuition.

Restrictions: Scholarly journals (Peer reviewed), References available.

Analysis: 1. number of publications, 2. analysis of the subjects and sub-subjects, 3. number of consequent citations.

In our analysis, we chose the approach of the thematic intersections of Marketing - Ethics Learning. We focused our analysis on a relatively narrow area of marketing journals only, while also monitoring a wider range of scientific journals of other related areas: e.g. management, accounting, communication, and management education.

As inspiration, we used the method of the abovementioned authors Schlegelmilch and Obersedeer (2010) on the basis of which we conducted our survey, summarized in Table 1. In order to find optimal results (i.e. articles devoted to education in the field of marketing ethics), we tested a different combination of logical operators in each individual database: EBSCO, ProQuest, Web of Science, Google Scholar. Among the frequently used databases for bibliographic research is $\mathrm{ABI} /$ Inform (Tucker, 2006); however, we opted for the Business Source Premier database (part of EBSO), which is one of the most comprehensive databases, in terms of quantity and time range of periodicals, providing access to full-text documents (Nill \& Schibrowsky, 2004).
This database provides empirical data, research findings, theory, as well as the new knowledge in the field of business and related areas, such as accounting, finance, economics (Golderman \& Connolly, 2009).

\subsection{Analysis of academic journals in the field of marketing ethics education}

We identified 718 articles based on the topic of education and ethics in economics and management where we considered only scientific peer-reviewed scolarly journals. The abovementioned overall number included 62 articles published in the field of "Ethics - Marketing - Training". We monitored journals identified in the previous research and chose those in which the number of articles exceeded five (see Table 1). Other publications were not included in the analysis presented here despite belonging among the most authoritative journals of business ethics, but they do not primarily focus on the issues represented by the intersection of our interest "Ethics - Marketing - Training". It can be argued that the journals shown in Table 1 are the cornerstones of our academic research in the field of education of marketing ethics.

TABLE 1: List of scientific journals with the largest number of publications in the field of marketing ethics

\begin{tabular}{|l|c|}
\hline Marketing* & Total (\%) \\
\hline Marketing Education Review & 31 \\
\hline Journal of Marketing Education & 24 \\
\hline Journal of Marketing & 7 \\
\hline
\end{tabular}

*Note: Business Search Premier database (Peer-reviewed, References Available), Journal of Management Education ERIC database, Subject Terms: (teaching or education), ethics, Publication Name: Marketing / Accounting / Management, etc.

Source: Authors

As we can see in the Table 1, the journals dealing with marketing ethics education are Journal of Marketing Education and Marketing Education Re- 
view. Journal of Marketing focused on marketing ethics in general, with most articles published in the 1960s and 1970s. Other important sources of business ethics teaching appear in the field of accounting, business, and management.

In the following section, we will analyze articles focusing on marketing ethics education, based on the content analysis, number of citations and publications, with the objective to understand the structure and trends of the academic research in this area. In the analysis, we include journals containing publications focusing on teaching marketing ethics (see Table 2). Table 2 shows the ranking of journals as regards the quantity of publications, citations and impact factor, alongside with the analysis by the thematic category.
In the final evaluation, we included 72 articles from four journals, where we analyzed the theme and the number of subsequent citations. If the article was not directly related to education in the field of marketing ethics, we did not include it in the survey.

We did not use any restriction with regard to the date of publication since we find the articles and their conclusions to be valid and topical. Earlier articles provide the foundation of knowledge on which new research builds nowadays. Very occasionally, on an individual basis, we excluded a few articles published in 1960s and 1970s in Journal of Marketing as they were thematically out of date.

TABLE 2: Overview of publications, citations and impact factors of journals for a specific area of education and teaching ethics in marketing, with the structure of thematic areas

\begin{tabular}{|c|c|c|c|c|c|c|c|c|c|}
\hline & & 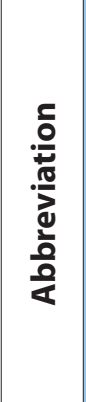 & 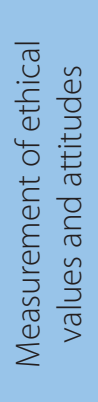 & 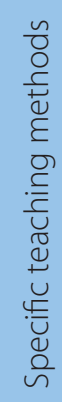 & 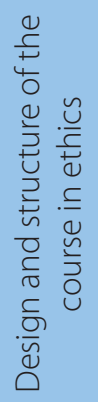 & 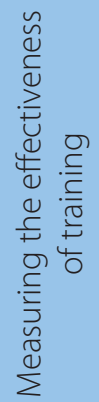 & 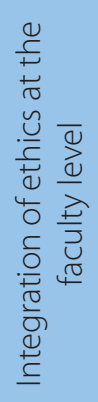 & 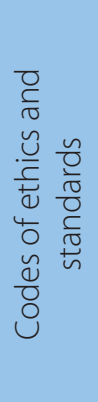 & $\begin{array}{l}\bar{\Xi} \\
\stackrel{0}{\circ}\end{array}$ \\
\hline \multirow{5}{*}{ 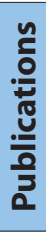 } & Marketing Education Review & MER & 8 & 14 & 2 & 2 & 3 & 1 & 30 \\
\hline & Journal of Marketing Education & JME & 9 & 9 & 4 & 1 & 1 & - & 24 \\
\hline & Journal of Business Ethics & JBE & 6 & - & 1 & 2 & - & 3 & 12 \\
\hline & Teaching Business Ethics & TBE & 4 & 2 & - & - & - & - & 6 \\
\hline & \multicolumn{2}{|l|}{ Total } & 27 & 25 & 7 & 5 & 4 & 4 & 72 \\
\hline \multirow{5}{*}{$\frac{\text { 을 }}{\stackrel{0}{*}}$} & Journal of Business Ethics & JBE & 194 & - & 8 & 35 & - & 8 & 245 \\
\hline & Journal of Marketing Education & JME & 83 & 27 & 8 & 4 & 0 & - & 122 \\
\hline & Marketing Education Review & MER & 36 & 49 & 4 & 2 & 6 & 7 & 104 \\
\hline & Teaching Business Ethics & TBE & 27 & 17 & - & - & - & - & 44 \\
\hline & \multicolumn{2}{|l|}{ Total } & 340 & 93 & 20 & 41 & 6 & 15 & 515 \\
\hline \multirow{5}{*}{ 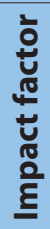 } & Journal of Business Ethics & JBE & 32.3 & - & 8.0 & 17.5 & - & 2.7 & 20.4 \\
\hline & Teaching Business Ethics & TBE & 6.8 & 8.5 & - & - & - & - & 7.3 \\
\hline & Journal of Marketing Education & JME & 9.2 & 3.0 & 2.0 & 4.0 & 0.0 & - & 5.1 \\
\hline & Marketing Education Review & MER & 4.5 & 3.5 & 2.0 & 1.0 & 2.0 & 7,0 & 3.5 \\
\hline & \multicolumn{2}{|l|}{ Average } & 12.6 & 3.7 & 2.9 & 8.2 & 1.5 & 3.8 & 7.2 \\
\hline
\end{tabular}

Source: Authors (own research and calculations) 
For the purpose of our research, we grouped the articles into thematic categories. Based on a detailed review of articles, we proposed six categories with the objective to provide: 1. consistent and relevant categorization of articles, and 2. clear and understandable trends in the academic research. Categories were designed very distinctly, following both empirical and academic logic.

Measurement of ethical values and attitudes. This group includes articles in which ethical education and training are interconnected with the measurement of ethical values. Most typical for this group of articles are comparative surveys among students of business schools, marketing professionals and various cross-cultural studies. In Table 3, we see that this topic is the most frequent and enjoys the highest interest of the academic community. The citations/publications ratio of 12.6 is relatively high; this is due to the fact that this topic provides the biggest opportunities for research, as well as for empirical applications.

Description of teaching methods is the second most frequent theme, where the authors describe a specific educational activity in detail and its practical implications for the learners as well as teachers. However, in this type of articles the authors do not measure the efficiency of the teaching method or changes of attitudes and ethical values as results of the pedagogic activity/method, presented in the articles.

Measurement of efficiency of training methods. On the thematic border between the two above-mentioned categories stands a group of articles in which the researchers deal with the question of how different teaching/training methods influence the change of ethical values and attitudes. The citations/publications ratio of 8.2 shows the importance and pertinence of this subject in the academic community.

Design and structure of the course in ethics and Integration of ethical training at the faculty level.
These two categories are the least frequent, with the lowest level of citations. However, they are relevant as regards the research interest of this article: understanding of research trends in the field of education of marketing ethics and innovation in education.

TABLE 3: Categories of publications in the field of education of marketing ethics: frequency in \% and the impact factor (citation/ publications ratio)

\begin{tabular}{|l|c|c|}
\hline \multicolumn{1}{|c|}{ Topic } & $\begin{array}{c}\text { Frequency } \\
\text { in \% }\end{array}$ & $\begin{array}{c}\text { Citations / } \\
\text { publications } \\
\text { ratio }\end{array}$ \\
\hline $\begin{array}{l}\text { Measurement } \\
\text { of ethical values } \\
\text { and attitudes }\end{array}$ & $\mathbf{3 8 \%}$ & 12.6 \\
\hline $\begin{array}{l}\text { Description } \\
\text { of teaching } \\
\text { methods }\end{array}$ & $\mathbf{3 5 \%}$ & 3.7 \\
\hline $\begin{array}{l}\text { Design and } \\
\text { structure of the } \\
\text { course in ethics }\end{array}$ & $\mathbf{1 0 \%}$ & 2.9 \\
\hline $\begin{array}{l}\text { Measurement } \\
\text { of efficiency } \\
\text { of training } \\
\text { methods }\end{array}$ & $\mathbf{7 \%}$ & 8.2 \\
\hline $\begin{array}{l}\text { Integrating } \\
\text { ethics at the } \\
\text { faculty level }\end{array}$ & $\mathbf{5 \%}$ & 1.5 \\
\hline $\begin{array}{l}\text { Standards and } \\
\text { the codes of } \\
\text { ethics }\end{array}$ & $\mathbf{5 \%}$ & 3.8 \\
\hline Total / average & $\mathbf{1 0 0 \%}$ & $\mathbf{7 . 2}$ \\
\hline
\end{tabular}

Source: Authors (own research and calculations)

The category of Standards and the codes of ethics was included because of its importance in marketing ethics in general. Figure 1 illustrates the representation of the categories in the respective journals. 
FIGURE 1: Number of publications in specialized journals in the field of education and teaching marketing ethics, with the structure of thematic areas

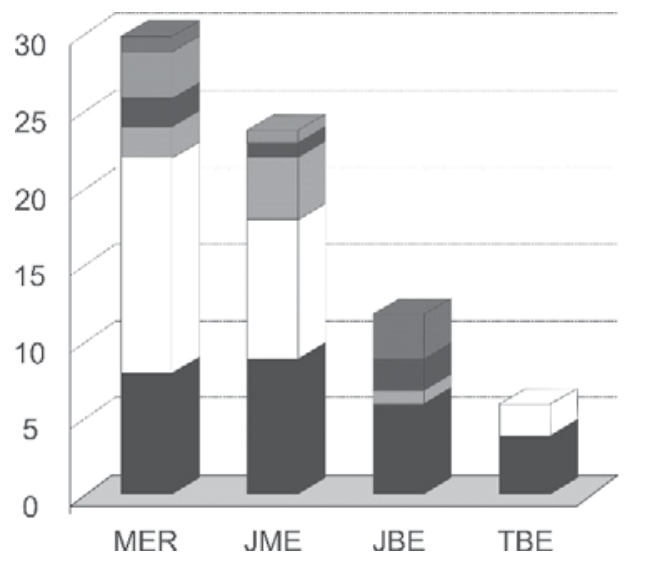

Source: Authors (own research and calculations)

In order to assess the quality of scientific journals, we use the impact factor, calculated as the ratio between the number of citations and the number of publications. In our survey, we work with the specific impact factor for the area of marketing ethics education (refer to the Figure 2).

FIGURE 2: Impact factor (number of citations to number of publications ratio) for the specific field of marketing ethics education

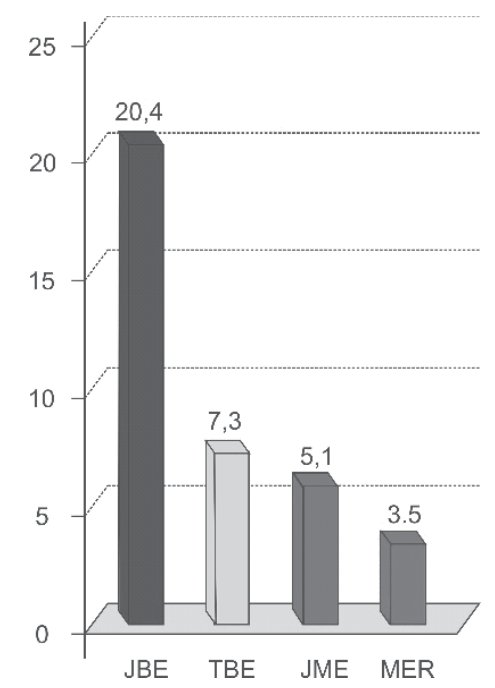

Source: Authors (own research and calculations)

\section{Legend}

Ethics codes and norms

- Integration of ethics at the faculty level

- Measure the effectiveness of education

Design and structure of the course in ethics

$\square$ Specific teaching methods

Measurement of ethical values and attitudes

Schlegelmilch and Obersedeer (2010) came out with an interesting analysis of the relationship between the number of publications and citations, which enables to monitor the interest of academic community and the importance of particular research trends. We used the same type of the graphical analysis for the field of marketing ethics education (see Ficture 3).

Figure 3 implies that the subject of Measuring ethical values and attitudes (6) attracts the majority of academic attention (by the number of publications) and has the highest impact on other researchers (by the number of citations). The second most attractive subject is the Description of specific teaching methods (5). Here the number of citations is high, depicting a strong continuity of the academic interest; on the other hand, the lower number of publications implies that the subject may concern a more specialized group of researchers, involved in teaching. Relatively important are the categories of Structure and design of the course in ethics (4) and the Measurement of effectiveness of ethical education (3). Other categories are of lower importance as regards the number of publication and citations, implying a highly specialized subfield on the periphery of the mainstream academic interest. 
FIGURE 3: Categories in the field of marketing ethics education - number of citations and publications

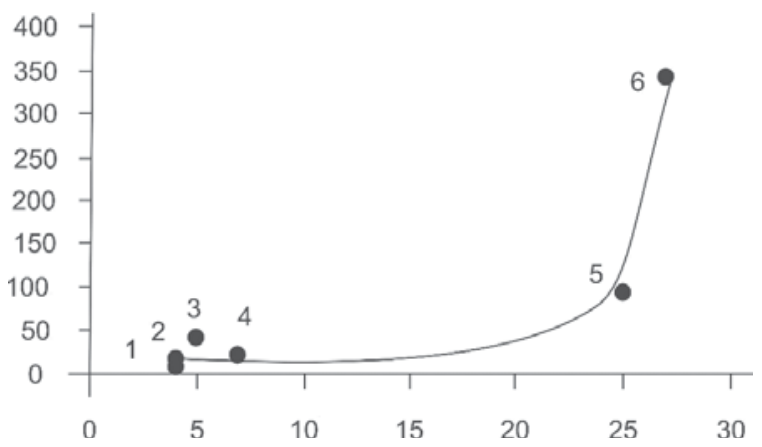

\section{Legend}

1 - Integration of ethics at the faculty level

2 - Ethics codes and standards

3 - Measure effectiveness of education

4 - Structure and design of the course in ethics

5 - Specific teaching methods

6 - Measurement of ethical values and attitudes

Source: Authors (own research and calculations)

\section{CONCLUSION}

The objective of this paper was to map academic resources, themes and research trends in the field of marketing ethics education, including a wide range of journals and articles. This resulted in a consistent conclusion: an intensification of efforts focused on promoting ethical education in marketing at universities means the creation of space for developing the moral potential of graduates and future business leaders. This research, to the best of our belief, helps to fulfill this ambition. The contribution of this article consists in the actualization of the state of knowledge in the field of marketing ethics education, as the last similar survey dates back to 2001 (Loe \& Ferell, 2001).

Innovative aspects of our work can be seen in the following: 1. We created a comprehensive and synthetic overview of a relatively complex field with a number of ad hoc issues. 2. To a large extent, we managed to respect the details and specificities of the given field.

Ethical education deserves further attention as its impact is not only at the superficial level of hard knowledge; it also influences a deeper inner level of personality which, ultimately, redefines the overall quality and sustainability of the business environment. In line with the opinion poll among French marketing academicians, the most important element in teaching ethics is the creation of "genuine ethical attitudes" among students, as future business leaders (Flipo, 2003).

Based on the research, as well as our experience, we present the following recommendations in the field of marketing ethics education at universities:

o create educational programs in line with the evidence-based principles, benefiting from the results of scientific research in the field of educational efficiency, harnessing efficiently cognitive skills, socio-emotional and moral dimensions of students;

o promote implementation of innovative teaching methods (e.g. based on the analysis of case studies with experiential elements), with the aim to foster the educational impact;

- create and develop a discussion forum for teachers, academicians, professionals, and others interested in the area;

o facilitate networking and collaboration among research institutions and business.

If we want to make the marketplace more effective over the long term, it needs to be based on firm and sustainable moral and ethical principles. The authors of this article hope that this 
article will serve for the promotion and development of these principles.

We can summarize our findings resulting from the research as follows. Discussions of academicians, specialists and students about marketing ethics and ethical issues are useful and important. Students need preparation, mentoring, and counselling while solving ethical problems, which occur during marketing ethics tuition in the academic field, but also in practice. Academic and scientific sources in the area of marketing ethics education are an excellent "instruction". In the centre of academic interest in the area of marketing ethics there are topics about academic methods and measurements of ethical values and attitudes related, above all, to marketing education. Marketing ethics should include tuition of one or several topics: marketing principles, marketing management, strategic marketing, marketing research, digital/ new marketing media, services marketing, and trade marketing.

Efforts to present the review of academic papers are rather rare, so the research in this field should be encouraged as it yields great value for researchers as well as teachers. The limitation of this research is evident in the fact that we focused especially on the marketing aspect of the ethics education. Other fields of interest, for example, management, accounting or commercial practices, etc., should be addressed in furture research.

\section{References}

1. Andersen, A. R. (2001). Ethics in social marketing. Washington, DC: Georgetown University Press.

2. Anderson, J. (1997). What Cognitive Science Tells Us About Ethics and The Teaching of Ethics. Journal of Business Ethics, 16, 270-290.

3. Baker, J., \& Saren, M. (2010). Marketing Theory: A Student Text. London: SAGE Publications Ltd.

4. Barnett, S. T., Dascher, P. E., \& Nicholson, C. Y. (2004). Can School Oversight Adequately Assess Department Outcomes? A Study of Marketing Curriculum Content. Journal of Education for Business, 79(3), 157-162.

5. Bauman, Z. (1995). Life in Fragments: Essays in Postmodern Morality. Oxford: Blackwell.

6. Baxter, G. D., \& Rarick, C. A. (1997). Education for the Moral Development of Managers: Kohlberg's Stages of Moral Development and Integrative Education. Journal of Business Ethics, 16, 243-248.

7. Brenkert, G. G. (2008). Marketing Ethics (Foundations of Business Ethics) (15t ed.). Oxford: Wiley-Blackwell.

8. Brennan, R., Nick, L. E., \& Higgins, M. (2010). Of a complex sensitivity in marketing ethics education. Journal of Marketing Management, 26(13), 1165-1180.

9. Buff, C. L., \& Yonkers, V. (2004). How Will They Know Right from Wrong? A Study of Ethics in the Mission Statements and Curriculum of AACSB Undergraduate Marketing Programs. Marketing Education Review, 14(3), 71-79.

10. Butorácová, I. (2009). Etické zásady a ich dominantné postavenie v marketingovej praxi európskeho trhového prostredia. Available on: http://www.mandk.cz/view.php?cisloclanku=2009050008

11. Chonko, L. B. (2004). Casuistry and change readiness: Fundamental aspects of teaching ethics in marketing decision making. Marketing Education Review, 14(3), 23-45.

12. Cragg, W. (1997). Teaching Business Ethics: The Role of Ethics in Business and in Business Education. Journal of Business Ethics, 16, 231-245.

13. Flipo, J. P. (2003). Ethics and Marketing: French Marketing Academics Express Stiff Critics. École de Management de Lyon. Available on: http://www.mngt.waikato.ac.nz/ejrot/cmsconference/2003/ proceedings/criticalmarketing/Flipo.pdf 
14. Gaski, J. F. (1999). Does marketing ethics really have anything to say? - a critical inventory of the literature. Journal of Business Ethics, 18(3), 315-334.

15. Golderman, G., \& Connolly, B. (2009). Getting Down to Business. Library Journal, 134(1), 16-22.

16. Haas, A. (2005). Now is the Time for Ethics in Education. CPA Journal, June, 1-5. Available on: http://www.nysscpa.org/cpajournal/2005/605/essentials/p66.htm

17. Harris, H. (2008). Promoting Ethical Reflection in the Teaching of Business Ethics. Business Ethics: A European Review, 17(4), 379-390.

18. Hunt, S. D., \& Laverie, D. A. (2004). Experiential Learning and the Hunt-Vitell Theory of Ethics: Teaching Marketing Ethics by Integrating Theory and Practice. Marketing Education Review, 14(3), $1-14$.

19. Kotler, P., \& Armstrong, G. (2004). Marketing. Praha: Grada.

20. Kotler, P., \& Armstrong, G. (2010). Principles of marketing. Essex: Pearson Education.

21. Lewis, P. V. (1985). Defining Business Ethics: Like Nailing Jello to a Wall. Journal of Business Ethics, 4 , 839-853.

22. Loe, T. W., \& Ferell, L. (2001). Teaching Marketing Ethics in the $21^{\text {st }}$ Century. Marketing Education Review, 11(2), 1-16.

23. Martin, T. R. (1985). Ethics in marketing: problems and prospects. In: G. Laczniak \& P. E. Murphy (Eds.). Marketing Ethics: Guideline for Managers. Lexington, MA: Lexington Books.

24. McAlister, D. T., Ferrell, O. C., \& Ferrell, L. (2010). Business and Society: A Strategic Approach to Social Responsibility (4 ${ }^{\text {th }}$ ed.) Boston, MA: Houghton Mifflin Company.

25. Murphy, P. E., \& Laczniak, G. R. (2006). Marketing Ethics: Cases and Readings. Boston, MA: Prentice Hall.

26. Nill, A., \& Schibrowski, J. A. (2004). Research on Marketing Ethics: A Systematic Review of the Literature. Journal of Macromarketing, 27, 256-273.

27. Porter, L. W., \& McKibbin, L. E. (1988). Management Education and Development: Drift or Thrust Into the $21^{\text {st }}$ Century. New York, NY: McGraw Hill.

28. Raisner, J. A. (1997). Using the Ethical Environment' Paradigm to Teach Business Ethics: The Case of the Maquiladoras. Journal of Business Ethics, 16, 1331-1346.

29. Ruiz, P. O. (2004). Moral education as pedagogy of alterity. Journal of Moral Education, 33(3), 271289.

30. Schlegelmich, B. B., \& Obersedeer, M. (2010). Half a Century of Marketing Ethics: Shifting Perspectives and Emerging Trends. Journal of Business Ethics, 93, 1-19.

31. Schminke, M. (2001). Considering the Business in Business Ethics: An Exploratory Study of the Influence of Organizational Size and Structure on Individual Ethical Predispositions. Journal of Business Ethics, 30, 370-390.

32. Shannon, J. R., \& Berl, R. L. (1997). Are we teaching ethics in marketing? A survey of students attitudes and perceptions. Journal of Business Ethics, 16, 1059-1075.

33. Spain, J. W., Engle, A. D., \& Thompson, J. C. (2005). Applying Multiple Pedagogical Methodologies in an Ethics Awareness Week: Expectations, Events, Evaluations and Enhancement. Journal of Business Ethics, 58(1-3), 716.

34. Tadajewski, M. (2008). Final thoughts on amnesia and marketing theory. Marketing Theory, 8(4), 465-484.

35. Tucker, J. C. (2006). Taking care of business: Selecting the best periodical database for your business patrons. Journal of Business and Finance Librarianship, 11(4), 23-44.

36. Wolfe, J., \& Fritzsche, D. (1998). Teaching Business Ethics with Management and Marketing Games. Simulation \& Gaming, 29(1), 44-59. 